\title{
Frank's sign: a coronary artery disease predictor
}

\author{
Risheng $\mathrm{Xu}^{1}{ }^{1}$ John Pham ${ }^{2}$
}

${ }^{1}$ Lyndon Baines Johnson Hospital, Houston, Texas, USA ${ }^{2}$ University of Texas HSC at Houston Medical School Houston, Texas, USA

\section{Correspondence to}

Dr Risheng Xu, rishengxu82@gmail.com

Accepted 29 June 2014

\section{DESCRIPTION}

A 69-year-old man with follicular lymphoma was admitted for initiation of chemotherapy. On physical examination, the patient was found to have anterior chest median sternotomy scar, also with bilateral

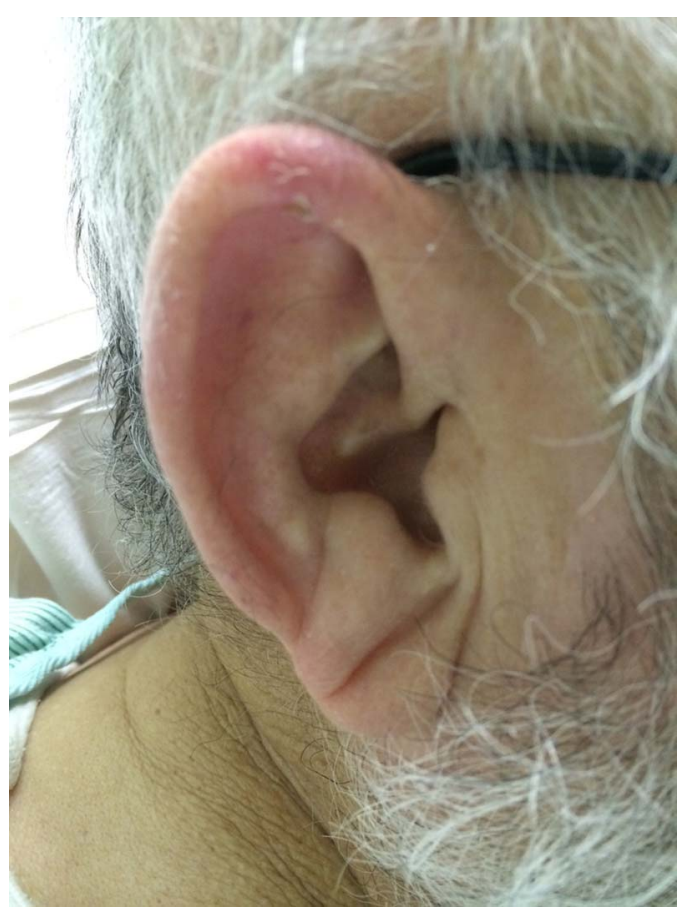

Figure 1 Right ear.

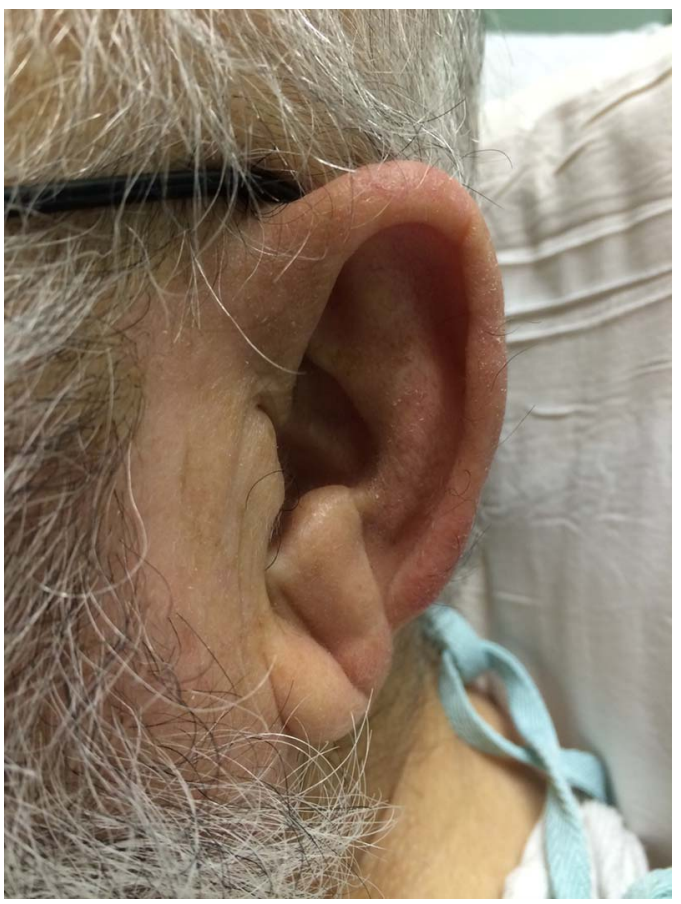

Figure 2 Left ear. diagonal earlobe creases runs backward at $45^{\circ}$ angle as shown in (figures 1 and 2). On further questioning, the patient revealed a history of single coronary artery bypass surgery 10 years ago. His clinical history and examination are consistent with Frank's sign. First described in 1973, Frank's sign is hypothesised to be a dermatological predictor of coronary artery disease, ${ }^{1}$ with significant reported association of increased ischaemic heart disease and myocardial infarctions in a large population prospective study of 35 years data collection. ${ }^{2}$ Circulating free radical oxidative stress was postulated as potential explanation to the dermatological changes and increases in intima-median thickness of blood vessels. ${ }^{3}$ Frank's sign is associated with ageing, but is a useful diagnostic physical examination in adults less than 60 years of age. ${ }^{4}$ Our patient did not have any cardiac symptoms, but due to the history of coronary artery disease and advanced age was recommended to have outpatient routine follow-up with primary care physician and risk reduction management.

\section{Learning points}

- Frank's sign is a diagonal earlobe crease that extends $45^{\circ}$ backwards from the tragus to the auricle, which is hypothesised to be a predictor of atherosclerotic disease.

- Large population prospective study has shown significant association of Frank's sign with increased risks of ischaemic heart disease and myocardial infarctions. It shows possibility of being independent risk factor and may predict severity for coronary artery disease.

- Reliable clinical correlations that predict atherosclerosis are needed to identify at-risk patients. Frank's sign has usefulness being a diagnostic physical examination finding in adults less than 60 years of age.

Contributors RX has contributed in case selection, final review and editing. JP has contributed in writing of the case.

Competing interests None.

Patient consent Obtained.

Provenance and peer review Not commissioned; externally peer reviewed.

\section{REFERENCES}

1 Celik S, Erdogan T, Gedikli O, et al. Diagonal ear-lobe crease is associated with carotid intima-media thickness in subjects free of clinical cardiovascular disease. Atherosclerosis 2007;192:428-31.

2 Christoffersen M, Frikke-Schmidt R, Schnohr $P$, et al. Visible age-related signs and risk of ischemic heart disease in the general population: a prospective cohort study. Circulation 2014;129:990-8

3 Fabijanic D, Culic V. Diagonal ear lobe crease and coronary artery disease. Am J Cardiol 2012:110:1385-6.

4 Griffing G. Images in clinical medicine. Frank's sign. N Engl J Med 2014:370:e15. 


\section{Images in...}

Copyright 2014 BMJ Publishing Group. All rights reserved. For permission to reuse any of this content visit http://group.bmj.com/group/rights-licensing/permissions.

BMJ Case Report Fellows may re-use this article for personal use and teaching without any further permission.

Become a Fellow of BMJ Case Reports today and you can:

- Submit as many cases as you like

- Enjoy fast sympathetic peer review and rapid publication of accepted articles

- Access all the published articles

- Re-use any of the published material for personal use and teaching without further permission

For information on Institutional Fellowships contact consortiasales@bmjgroup.com

Visit casereports.bmj.com for more articles like this and to become a Fellow 